\title{
Synthesis, thermal study and some properties of Gd(III), Tb(III), Dy(III) and Er(III) complexes with $4,4^{\prime}$-bipyridine and dibromoacetates
}

\author{
A. Czylkowska ${ }^{1}$
}

Received: 19 November 2014/Accepted: 25 March 2015/Published online: 16 April 2015

(C) The Author(s) 2015. This article is published with open access at Springerlink.com

\begin{abstract}
New complexes with formulae: $\mathrm{Ln}(4-\mathrm{bpy})\left(\mathrm{CBr}_{2-}\right.$ $\mathrm{HCOO})_{3} \cdot 3 \mathrm{H}_{2} \mathrm{O} \quad$ (where $\left.\mathrm{Ln}(\mathrm{III})=\mathrm{Gd}, \quad \mathrm{Tb}, \quad \mathrm{Dy}\right)$ and $\mathrm{Er}(4-\text { bpy })_{1.5}\left(\mathrm{CBr}_{2} \mathrm{HCOO}\right)_{3} \cdot 3 \mathrm{H}_{2} \mathrm{O}$, were prepared and characterized by chemical, elemental analysis and IR spectroscopy. The nature of metal-ligand coordination was studied. All of them are crystalline. Gd(III), Tb(III) and Dy(III) complexes are isostructural in one group. Conductivity studies (in methanol, dimethyloformamide and dimethylsulfoxide) were also discussed. The thermal properties of complexes in the solid state were studied using TG-DTG techniques under dynamic flowing air atmosphere. TG-MS system was used for $\mathrm{Tb}$ (III) (as an example of isostructural compound) and $\mathrm{Er}$ (III) complexes to analyze principal volatile thermal decomposition and fragmentation products evolved during pyrolysis in dynamic flowing air atmosphere.
\end{abstract}

Keywords Heavy lanthanide complexes $\cdot 4,4^{\prime}$ -

Bipyridine $\cdot$ Dibromoacetates $\cdot$ TG-DTG $\cdot$ TG-MS $\cdot$ IR spectra

\section{Introduction}

Lanthanide compounds including $\mathrm{N}$ and $\mathrm{O}$ donors, as bipyridine isomers and carboxylate groups, are still the subject of current research. Based on the trend of lanthanides to create high coordination numbers and possibility of different coordination of selected organic ligands, it may be stated that such complexes can create a new class of compounds with

A. Czylkowska

agnieszka.czylkowska@p.lodz.pl

1 Institute of General and Ecological Chemistry, Lodz University of Technology, Lodz, Poland potentially different functions and application. The mixed halogeno-bipyridine complexes of lanthanide(III) have been the subject of investigation for several years. The nature of bonds between $\operatorname{Ln}(\mathrm{III})$ ions and halogenoacetate ligand and bipyridine isomers is discussed in several papers [1-5]. These mixed ligand complexes are of interest because of possibility of various ways of coordination bipyridine and halogenoacetate ligands. These ligands are able to exist as mono- and multidentate donors in metal complexes [1-5]. In the literature $[1,2]$, there are described compounds, where there is only one type of coordination of carboxylate ligands. The papers [3-10] are examples to occur different possibilities of binding $\mathrm{COO}$ groups in one compound.

It is interesting to compare the properties of the mixed ligand lanthanide(III) complexes with 4,4'-bipyridine and chloro- or bromoacetates. These researches are recently undertaken in our laboratory.

Previously, the synthesis and characterization of lanthanide(III) complexes (where $\mathrm{Ln}(\mathrm{III})=\mathrm{Y}, \mathrm{La} \rightarrow \mathrm{Lu}$ without Pm(III)) with 4,4'-bipyridine and di- or trichloroacetates were reported [6-14]. This paper presents the results of new lanthanide complexes with title ligands. It is a continuation of our study on preparation, type of coordination organic ligands and thermal behavior of $\mathrm{Y}(4-\mathrm{bpy})_{1.5}\left(\mathrm{CBr}_{2} \mathrm{HCOO}\right)_{3} \cdot 3 \mathrm{H}_{2} \mathrm{O}$, $\mathrm{Ln}\left(4\right.$-bpy) $\left(\mathrm{CBr}_{2} \mathrm{HCOO}\right)_{3} \cdot \mathrm{nH}_{2} \mathrm{O}$ where $\mathrm{Ln}(\mathrm{III})=\mathrm{La}, \mathrm{Ce}, \mathrm{Eu}$ and $\mathrm{Ln}(4-\text { bpy })_{0.5}\left(\mathrm{CBr}_{2} \mathrm{HCOO}\right)_{3} \cdot 2 \mathrm{H}_{2} \mathrm{O}$ where $\mathrm{Ln}(\mathrm{III})=\mathrm{Pr}$, $\mathrm{Nd}, \mathrm{Sm}$ complexes $[14,15]$.

\section{Experimental}

Materials, synthesis and analysis

4,4'-Bipyridine, $\mathrm{CBr}_{2} \mathrm{HCOOH}, \mathrm{Ln}_{2} \mathrm{O}_{3}$ (where $\mathrm{Ln}(\mathrm{III})=$ $\mathrm{Gd}$, Dy), $\mathrm{Tb}_{4} \mathrm{O}_{7}, \mathrm{Er}_{2} \mathrm{O}_{3}$, dimethylsulfoxide (DMSO), 
Table 1 Analytical data and molar conductivity in $\mathrm{MeOH}$, DMF and DMSO for investigated complexes

\begin{tabular}{|c|c|c|c|c|c|c|c|}
\hline \multirow[t]{2}{*}{ Compound } & \multicolumn{4}{|c|}{ Analysis: found (calculated) $(\%)$} & \multicolumn{3}{|c|}{$\Lambda_{\mathrm{M}}\left(\Omega^{-1} \mathrm{~cm}^{2} \mathrm{~mol}^{-1}\right) ; c=1 \times 10^{-3} \mathrm{~mol} \mathrm{dm}^{-3}$} \\
\hline & $\mathrm{Ln}$ & $\mathrm{C}$ & $\mathrm{N}$ & $\mathrm{H}$ & $\mathrm{MeOH}$ & DMF & DMSO \\
\hline $\mathrm{Gd}(4-\mathrm{bpy})\left(\mathrm{CBr}_{2} \mathrm{HCOO}\right)_{3} \cdot 3 \mathrm{H}_{2} \mathrm{O}$ & $15.55(15.45)$ & $18.90(18.88)$ & $2.82(2.75$ & $1.67(1.68)$ & 55.0 & 49.1 & 52.0 \\
\hline $\mathrm{Tb}(4-\mathrm{bpy})\left(\mathrm{CBr}_{2} \mathrm{HCOO}\right)_{3} \cdot 3 \mathrm{H}_{2} \mathrm{O}$ & $16.03(15.58)$ & $18.88(18.85)$ & $2.81(2.75)$ & $1.67(1.68)$ & 52.2 & 48.8 & 54.3 \\
\hline Dy (4-bpy) $\left(\mathrm{CBr}_{2} \mathrm{HCOO}\right)_{3} \cdot 3 \mathrm{H}_{2} \mathrm{O}$ & $15.96(15.88)$ & $18.82(18.78)$ & $2.80(2.74)$ & $1.69(1.67)$ & 54.4 & 46.2 & 53.0 \\
\hline $\mathrm{Er}(4-\mathrm{bpy})_{1.5}\left(\mathrm{CBr}_{2} \mathrm{HCOO}\right)_{3} \cdot 3 \mathrm{H}_{2} \mathrm{O}$ & $15.15(15.12)$ & $22.74(22.80)$ & $3.74(3.80)$ & $1.90(1.91)$ & 51.0 & 42.5 & 50.0 \\
\hline
\end{tabular}

dimethylformamide (DMF) and methanol (MeOH) (anhydrous) p.a. were obtained from Aldrich and Lab-Scan, respectively. Water solutions of metal(III) dibromoacetates

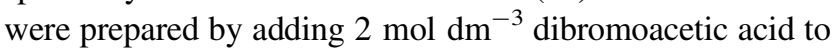
freshly precipitated hydroxides in ca. stoichiometric quantities (in temperature $\leq 18{ }^{\circ} \mathrm{C}$, because lanthanide dibromoacetate solutions are relatively unstable; in the presence of 4-bpy these stability increased).

The mixed ligand complexes were synthesized in the same way as we described in [15]. The contents of metal(III) ions in obtained solutions were mineralized and determined by EDTA titration.

The carbon, hydrogen and nitrogen contents in the prepared complexes were determined by a Carlo-Erba analyzer with $\mathrm{V}_{2} \mathrm{O}_{5}$ as an oxidizing agent.

\section{Methods and instruments}

The X-ray powder diffraction patterns of synthesized complexes and final solid decomposition products in air were recorded on D-5000 diffractometer using Ni-filtered $\mathrm{CuK}_{\alpha}$ radiation. The measurements were taken in the range of $2 \theta$ angles $2^{\circ}-80^{\circ}$. Obtained results were analyzed using the Powder Diffraction File [16]. Molar conductance was measured on a conductivity meter of the OK-102/1 type equipped with an OK-902 electrode at $25 \pm 0.5{ }^{\circ} \mathrm{C}$, using $1 \times 10^{-3} \mathrm{~mol} \mathrm{dm}^{-3}$ solutions of complexes in methanol, dimethylformamide and dimethylsulfoxide. IR spectra were recorded with a NICOLET 6700 Spectrometer (4000-400 $\mathrm{cm}^{-1}$ with accuracy of recording $1 \mathrm{~cm}^{-1}$ ) using $\mathrm{KBr}$ pellets. The thermal properties of complexes in air were studied by TG-DTG techniques in the range of temperature $25-1000{ }^{\circ} \mathrm{C}$ at a heating rate of $10{ }^{\circ} \mathrm{C} \mathrm{min}{ }^{-1}$; TG and DTG curves were recorded on Netzsch TG 209 apparatus in flowing dynamic air atmosphere $v=20 \mathrm{~cm}^{3} \mathrm{~min}^{-1}$ using ceramic crucibles. The solid intermediate products of pyrolysis in air were determined from TG and DTG curves and confirmed by recording the IR spectra of sinters (prepared during heating the sample of complex up to appropriate temperature defined from the TG or DTG curves). The IR spectra of sinters were analyzed in the region characteristic for 4,4'-bipyridine and dibromoacetates absorption. Additionally, in the sinters, the presence of anions $\mathrm{Br}^{-}$was also investigated. The TG-MS coupled measurements have been carried out only for $\mathrm{Tb}(\mathrm{III})$ and Er(III) complexes using the SETSYS 16/18 apparatus coupled with QMS-422 Balzers spectrometer, in the range of temperature $25-1000{ }^{\circ} \mathrm{C}$ at a heating rate $10^{\circ} \mathrm{C} \mathrm{min}{ }^{-1}$ in flowing air atmosphere $v=20 \mathrm{~cm}^{3} \mathrm{~min}^{-1}$ in ceramic crucibles. The $m / z$ values are given based on ${ }^{1} \mathrm{H},{ }^{12} \mathrm{C},{ }^{14} \mathrm{~N},{ }^{16} \mathrm{O}$ and ${ }^{80} \mathrm{Br}$ (additionally ${ }^{13} \mathrm{C}$ and ${ }^{18} \mathrm{O}$ in case of $\mathrm{CO}_{2}$ ).

\section{Results and discussion}

Table 1 presents results of the elemental and chemical analysis of investigated compounds. They are stable in air in solid state. The analysis of the power diffraction patterns of these compounds reveals that they are crystalline. Gd(III), Tb(III) and Dy(III) complexes are isostructural in one group (Fig. 1). The Er(III) compound is not isostructural with them. There are no powder diffraction patterns of reported complexes in Powder Diffraction File [16]. There were isolated monocrystals of Dy(III) compound, but they have very poor quality (not suitable data for publication). Also in Table 1, there are molar conductivity values for all complexes in solutions of $\mathrm{MeOH}, \mathrm{DMF}$ and DMSO. All complexes in $\mathrm{MeOH}$ and $\mathrm{DMF}$ display behaviors intermediate between those of nonelectrolytes and 1:1 electrolytes. In DMSO they are electrolyte type 1:1 [17]. In series of light lanthanide complexes (Ce(III) $\rightarrow \mathrm{Eu}(\mathrm{III})$ ) with 4-bpy and dibromoacetates, the molar conductivities in solutions $\mathrm{MeOH}, \mathrm{DMF}$ and DMSO have similar values. Relative not high molar conductance in $\mathrm{MeOH}$ and DMF is characteristic for all complexes compared. The conductivity data suggest that dibromoacetate ligands in obtained compounds are only partially displaced by solvent molecules [18, 19].

\section{IR spectra}

In Tables 2 and 3, there are absorption bands in the region characteristic for dibromoacetates and 4-bpy. These spectra are very similar. For all compounds, the $v_{\text {as }}(\mathrm{COO})$ 
Fig. 1 X-ray diffraction patterns for complexes $\mathrm{Ln}(4-$ bpy) $\left(\mathrm{CBr}_{2} \mathrm{HCOO}\right)_{3} \cdot 3 \mathrm{H}_{2} \mathrm{O}$ $(\operatorname{Ln}(\mathrm{III})=\mathrm{Gd}, \mathrm{Tb}, \mathrm{Dy})$

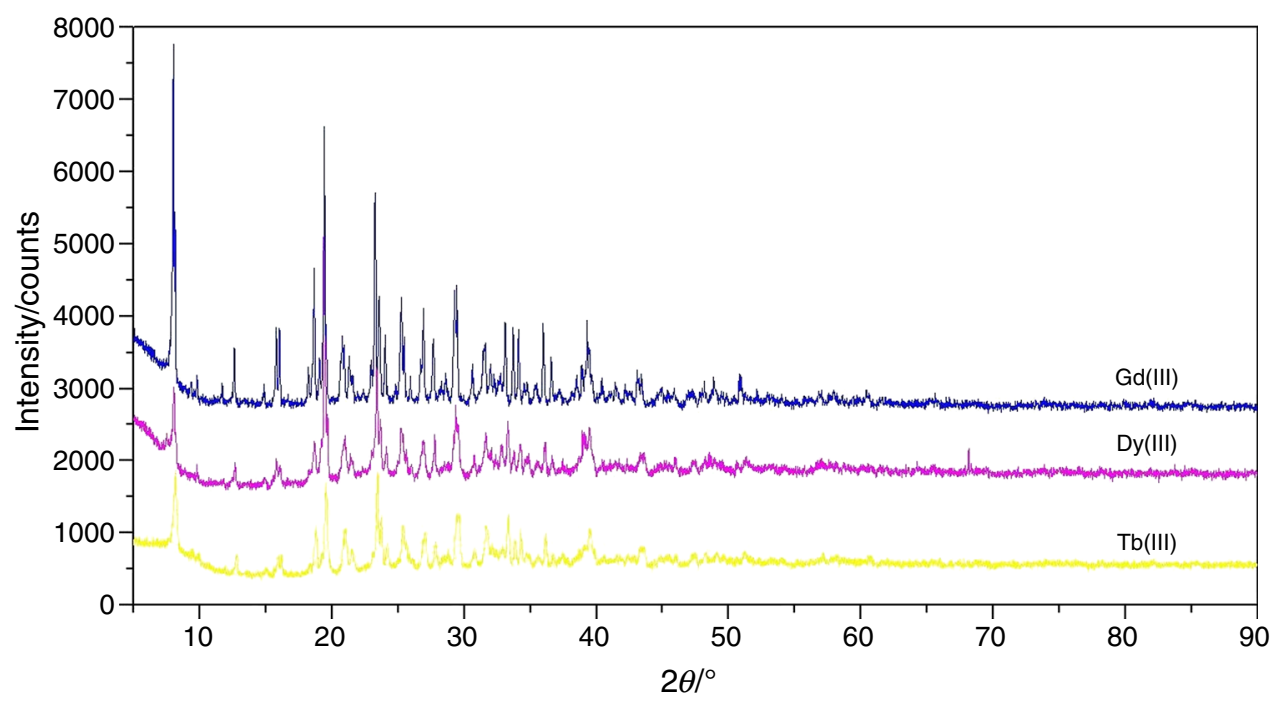

Table 2 IR bands of $\mathrm{CBr}_{2} \mathrm{HCOO}^{-}$groups in $\mathrm{CBr}_{2} \mathrm{HCOONa}$ and obtained complexes

\begin{tabular}{|c|c|c|c|c|c|}
\hline \multirow{2}{*}{$\mathrm{CBr}_{2} \mathrm{HCOONa}[20]$} & \multicolumn{4}{|c|}{ Complexes } & \multirow{2}{*}{ Assignments } \\
\hline & $\mathrm{Gd}(\mathrm{III})$ & $\mathrm{Tb}(\mathrm{III})$ & Dy(III) & $\operatorname{Er}(\mathrm{III})$ & \\
\hline 3015 & 2985 & 2985 & 2985 & 3022 & $v(\mathrm{CH})$ \\
\hline 1616 & 1708 & 1710 & 1712 & 1690 & $v_{\mathrm{as}}(\mathrm{COO})$ \\
\hline 1378 & 1389 & 1388 & 1390 & 1412,1385 & $v_{\mathrm{s}}(\mathrm{COO})$ \\
\hline 1191 & 1186 & 1186 & 1186 & 1181 & $v(\mathrm{CH})$ \\
\hline 1148 & 1145 & 1140 & 1141 & 1145 & $\delta(\mathrm{CCOO})$ \\
\hline 931 & 950 & 950 & 950 & 950 & $v(\mathrm{CC})$ \\
\hline 698 & 720 & 720 & 720 & 700 & $v_{\mathrm{s}}\left(\mathrm{CBr}_{2}\right)$ \\
\hline
\end{tabular}

vibration is identified as the strong band in the range $1712-1690 \mathrm{~cm}^{-1}$. The band assigned to the vibration of $v_{\mathrm{s}}(\mathrm{COO})$ is observed in the range $1412-1385 \mathrm{~cm}^{-1}$. Only for $\mathrm{Er}(\mathrm{III})$ complex, $v_{\mathrm{s}}(\mathrm{COO})$ vibrations are split into two. The vibrations of $v_{\mathrm{as}}(\mathrm{COO})$ and $v_{\mathrm{s}}(\mathrm{COO})$ are shifted to higher wave numbers. This fact may indicate that the carboxylate groups are bonded to metal(III) ions as bridging ligands [22-24]. For Er(III) compound, probably bridging non-completely equivalent bonds between $\operatorname{Er}($ III) and carboxylate groups exists [25]. In the absorption region of $\mathrm{CBr}_{2} \mathrm{HCOONa}$ appear also the stretching modes $v_{\mathrm{s}}\left(\mathrm{CBr}_{2}\right)$ and $\delta(\mathrm{CCOO})$. They are in complexes observed in the ranges: $700-720 \mathrm{~cm}^{-1}$ and between 1145 and $1140 \mathrm{~cm}^{-1}$, respectively. The absorption bands of $v(\mathrm{CH})$ are in the sodium salt at 3015 and $1191 \mathrm{~cm}^{-1}$; in the complexes, they are in the ranges: 3022-2986 and $1181-1186 \mathrm{~cm}^{-1}$.

In the IR spectra of complexes, there are also vibrations of 4-bpy. They are given in Table 3. The observations were made for 4-bpy absorption in the region $4000-600 \mathrm{~cm}^{-1}$. The characteristic band attributed to $v(\mathrm{CC}), v(\mathrm{CN}), v\left(\mathrm{CC}_{\mathrm{ir}}\right)$ vibrations (symmetry $A_{l}$ ) in pure 4-bpy is at $1588 \mathrm{~cm}^{-1}$, but in complexes, it is in the range $1615-1599 \mathrm{~cm}^{-1}$. The band in the free ligand at $1530 \mathrm{~cm}^{-1}$ assigned to $v(C C)$, $v(C C)$ vibrations (symmetry $B_{1}$ ) in the IR spectra of complexes, is slightly shifted to higher frequency. The band characteristic for "breathing" mode is moved to higher wave numbers $\left(1003-1000 \mathrm{~cm}^{-1}\right)$ in comparison with free ligand $\left(988 \mathrm{~cm}^{-1}\right)$. Most of aromatic ring deformation bands in plane $\gamma(\mathrm{CH})$ and out plane $\beta(\mathrm{CH})$ shift to lower and higher frequency after coordination with metal ion [21].

In addition, a broad band in the water stretching region (ca 3450-3350 $\mathrm{cm}^{-1}$ ) appears for all complexes described.

\section{Thermal decomposition in air}

The TG-DTG methods were used to describe thermal decomposition in air of synthesized complexes. First step of pyrolysis is dehydration. After that, partial decomposition and next total decomposition of organic ligands take place. Most processes are poorly separated from each other. In several intermediate solid products, presence of bromide, carboxylate group and bipyridine was identified. As a final, 
Table 3 IR bands for free 4-bpy and 4-bpy in obtained complexes

\begin{tabular}{|c|c|c|c|c|c|}
\hline \multirow[t]{2}{*}{ 4-bpy [21] } & \multicolumn{4}{|c|}{ Complexes } & \multirow[t]{2}{*}{ Assignments } \\
\hline & Gd(III) & $\mathrm{Tb}(\mathrm{III})$ & Dy(III) & $\operatorname{Er}(\mathrm{III})$ & \\
\hline 1588 & 1610 & 1600 & 1615 & 1599 & $v(\mathrm{CC}), v(\mathrm{CN}), v\left(\mathrm{CC}_{\mathrm{ir}}\right), A_{l}$ \\
\hline 1530 & 1535 & 1532 & 1531 & 1535 & $v(\mathrm{CC}), \mathrm{v}(\mathrm{CN}) B_{1}$ \\
\hline 1488 & 1490 & 1487 & 1490 & 1498 & $v(\mathrm{CC}), v(\mathrm{CN})$ \\
\hline 1403 & 1403 & 1404 & 1405 & 1403 & $v(\mathrm{CC}), v(\mathrm{CN})$ \\
\hline 1328 & 1320 & 1320 & 1320 & 1320 & $v(\mathrm{CC}), v(\mathrm{CN})$ \\
\hline 1205 & 1210 & 1205 & 1205 & 1219 & $\beta(\mathrm{CH})$ \\
\hline 1092 & - & - & - & - & $\beta(\mathrm{CH})$ \\
\hline 1072 & 1065 & 1066 & 1065 & 1066 & $\beta(\mathrm{CH})$ \\
\hline 1037 & 1045 & 1045 & 1045 & 1043 & "Ring breathing" \\
\hline 988 & 1000 & 1001 & 1000 & 1003 & "Ring breathing" \\
\hline 962 & $*$ & $*$ & $*$ & 970 & $\gamma(\mathrm{CH})$ \\
\hline 850 & 850 & 850 & 850 & 830 & $\gamma(\mathrm{CH})$ \\
\hline 810 & 806 & 806 & 806 & 805 & $\gamma(\mathrm{CH})$ \\
\hline 745 & 790 & 789 & 790 & - & $\gamma(\mathrm{CH})$ \\
\hline 733 & 735 & 733 & 733 & 730 & $\gamma(\mathrm{CH})$ \\
\hline 672 & 680 & 679 & 680 & 683 & $\gamma(\mathrm{CH})$ \\
\hline 608 & 620 & 619 & 620 & 623 & $\beta(\mathrm{CH})$ \\
\hline
\end{tabular}

ir-inter ring bands; $A_{l}$-symmetry $A_{l}, B_{l}$-symmetry $B_{l}$

* overlap by dibromoacetates absorption

Fig. 2 X-ray diffraction patterns for sinter of Dy(III) complex at $800{ }^{\circ} \mathrm{C}$ (pure $\mathrm{Dy}_{2} \mathrm{O}_{3}$ )

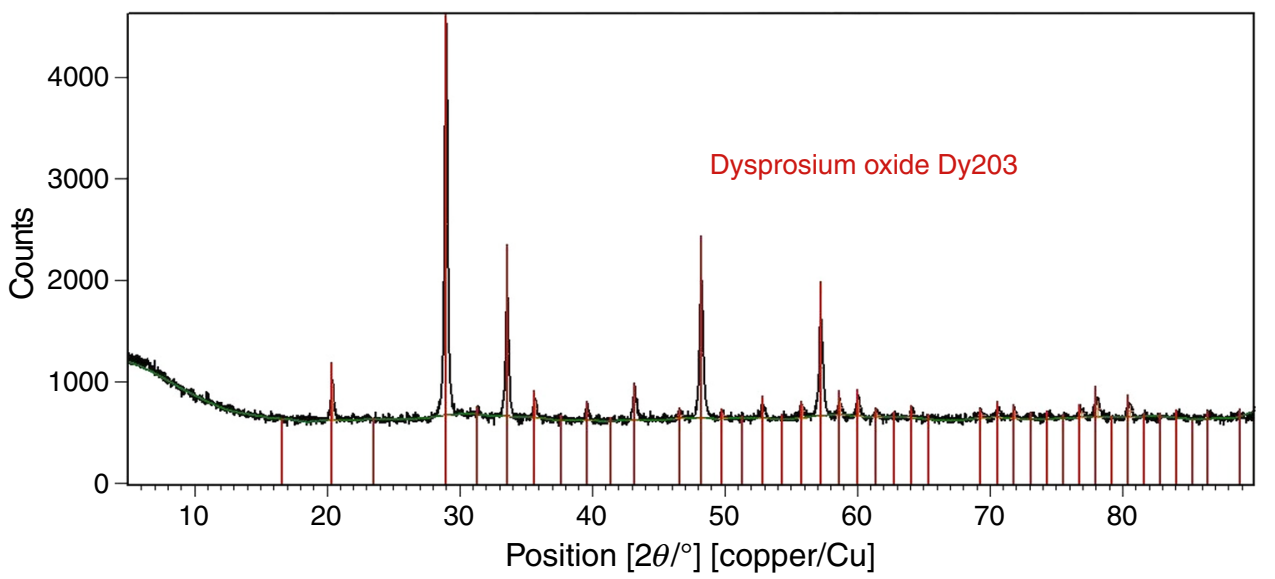

solid decomposition products are suitable lanthanide oxides. This has been proven on the basis of diffraction patterns (as an example Fig. 2) taken for final solid products. All synthesized compounds do not reveal the effect of creating LnOBr. Figures 3, 4, 56 show profiles of TG and DTG of all obtained complexes. Results of thermal analysis are presented in Table 4.

$\mathrm{Gd}(4-\mathrm{bpy})\left(\mathrm{CBr}_{2} \mathrm{HCOO}\right)_{3} \cdot 3 \mathrm{H}_{2} \mathrm{O}$ starts to decompose at $75^{\circ} \mathrm{C}$. In the temperature ranges: $75^{\circ}-100^{\circ}$ and 100-200 ${ }^{\circ} \mathrm{C}$, two-stage dehydration takes place. First, Gd(III) complex loses one water molecule and next two moles of water. Anhydrous compound is stable up to
$200{ }^{\circ} \mathrm{C}$. When temperature rises, partial decomposition of dibromoacetates occurs. Probably intermediate solid product appears, $\mathrm{Gd}(4-\mathrm{bpy})\left(\mathrm{CBr}_{2} \mathrm{HCOO}\right)_{2.75} \cdot \mathrm{Br}_{0.25}$ (mass lose calculated $3.67 \%$ and found $4.0 \%$ ). On DTG curve appears peak at $205{ }^{\circ} \mathrm{C}$. Next $\left(220-290{ }^{\circ} \mathrm{C}\right)$, there is further decomposition of halogenoacetates probably via $\mathrm{Gd}(4-$ bpy) $\left(\mathrm{CBr}_{2} \mathrm{HCOO}\right) \cdot \mathrm{Br}_{2}$ accompanied with strong maximum on DTG at $245^{\circ} \mathrm{C}$. Subsequent thermolysis of $\mathrm{Gd}(4-$ bpy) $\left(\mathrm{CBr}_{2} \mathrm{HCOO}\right) \cdot \mathrm{Br}_{2}$ is observed with DTG peaks at 330 , 440 and $815{ }^{\circ} \mathrm{C}$. Horizontal mass level for $\mathrm{Gd}_{2} \mathrm{O}_{3}$ begins at $835{ }^{\circ} \mathrm{C}$. 
Fig. 3 TG and DTG curves of thermal decomposition of $\mathrm{Gd}(4-\mathrm{bpy})\left(\mathrm{CBr}_{2} \mathrm{HCOO}\right)_{3} \cdot 3 \mathrm{H}_{2} \mathrm{O}$ recorded in air atmosphere; mass sample $6.32 \mathrm{mg}$
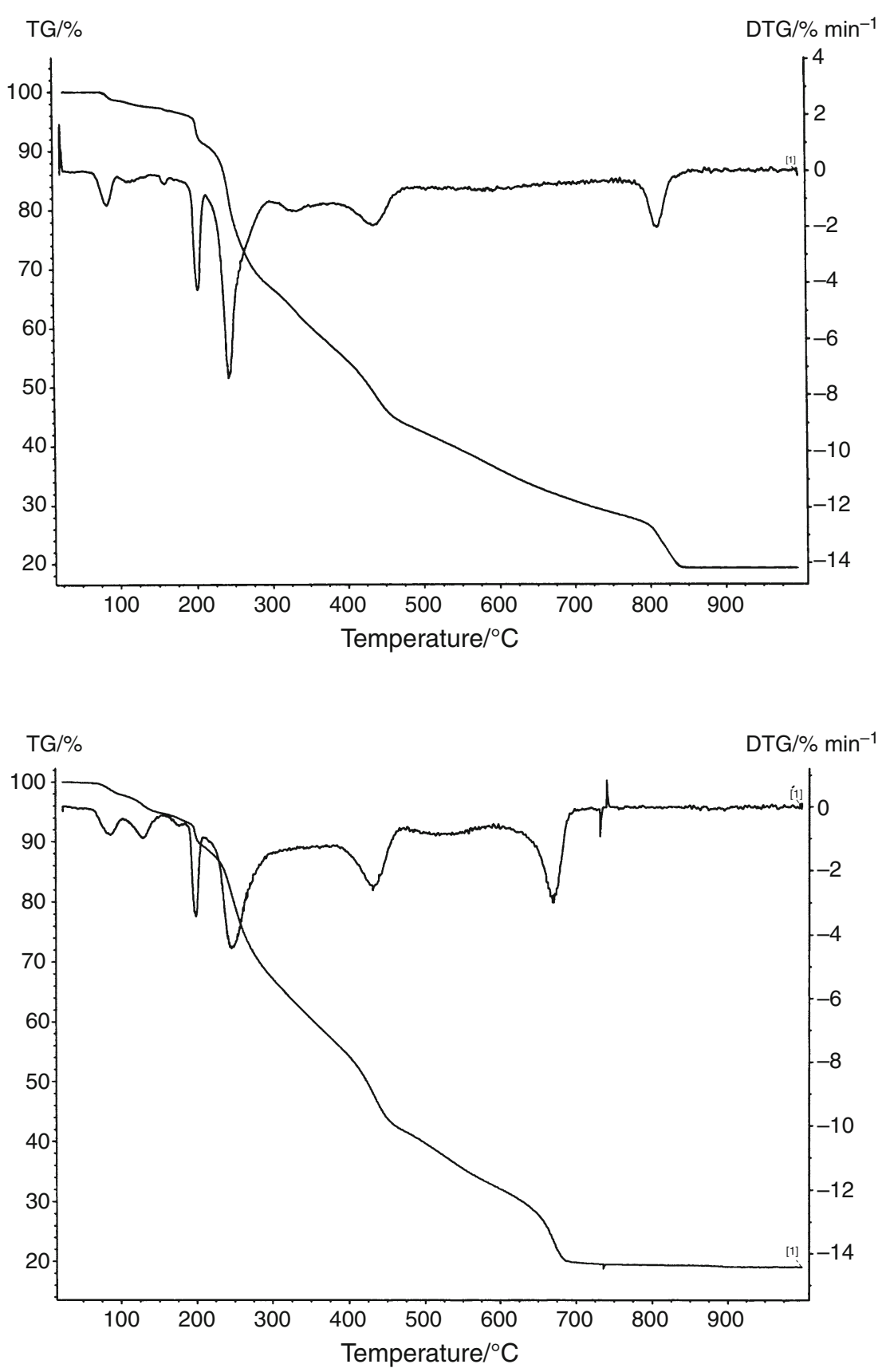

Fig. 4 TG and DTG curves of thermal decomposition of $\mathrm{Tb}$ (4-bpy) $\left(\mathrm{CBr}_{2} \mathrm{HCOO}\right)_{3} \cdot 3 \mathrm{H}_{2} \mathrm{O}$ recorded in air atmosphere; mass sample $8.90 \mathrm{mg}$
Terbium(III) complex decomposes, also as Gd(III) compound, at $75{ }^{\circ} \mathrm{C}$. First, it loses one and next two molecules of water. On DTG curve, there are two peaks at 80 and $135{ }^{\circ} \mathrm{C}$. Above $155^{\circ} \mathrm{C}, \mathrm{Tb}(4-\mathrm{bpy})\left(\mathrm{CBr}_{2} \mathrm{HCOO}\right)_{3}$ converts probably to $\mathrm{Tb}(4-\mathrm{bpy})\left(\mathrm{CBr}_{2} \mathrm{HCOO}\right)_{2.5} \cdot \mathrm{Br}_{0.5}$. It is accompanied with DTG peak at $200{ }^{\circ} \mathrm{C}$. Further heating causes decomposition of first partial and then total organic ligands (DTG maximum at 245, 430 and $660{ }^{\circ} \mathrm{C}$ ). These processes are poorly separated from each other. A plateau on TG curve for $\mathrm{Tb}_{4} \mathrm{O}_{7}$ begins above $750{ }^{\circ} \mathrm{C}$ (mass lose calculated $81.67 \%$ and found $81.3 \%$ ).
Dy(III) compound is stable up to $60^{\circ} \mathrm{C}$. On the beginning, complex loses $1.5 \mathrm{~mol}$ of water. In the range of temperature $125-200{ }^{\circ} \mathrm{C}$ further dehydration and decomposition to Dy(4-bpy) $\left(\mathrm{CBr}_{2} \mathrm{HCOO}\right)_{2.75} \cdot \mathrm{Br}_{0.25}$ take place (mass lose calculated $5.99 \%$ and found $6.0 \%$ ). This is connected with DTG peak at $185{ }^{\circ} \mathrm{C}$. Next $\left(200-350{ }^{\circ} \mathrm{C}\right)$, Dy(4-bpy) $\left(\mathrm{CBr}_{2}\right.$ $\mathrm{HCOO})_{0.5} \cdot \mathrm{Br}_{2.5}$ appears. After that, further pyrolysis (destruction of dibromoacetate groups and oxidation of organic fragments) takes place by the overlap of multiple processes. The DTG curve shows peaks at $250^{\circ}$ (with shoulder at $260^{\circ}$ ), 430 and $770{ }^{\circ} \mathrm{C}$. At $800{ }^{\circ} \mathrm{C}, \mathrm{Dy}_{2} \mathrm{O}_{3}$ forms. 
Fig. 5 TG and DTG curves of thermal decomposition of Dy(4-bpy) $\left(\mathrm{CBr}_{2} \mathrm{HCOO}\right)_{3} \cdot 3 \mathrm{H}_{2} \mathrm{O}$ recorded in air atmosphere; mass sample $9.96 \mathrm{mg}$
Fig. 6 TG and DTG curves of thermal decomposition of $\operatorname{Er}(4-b p y)_{1.5}$

$\left(\mathrm{CBr}_{2} \mathrm{HCOO}\right)_{3} \cdot 3 \mathrm{H}_{2} \mathrm{O}$ recorded in air atmosphere; mass sample $10.36 \mathrm{mg}$
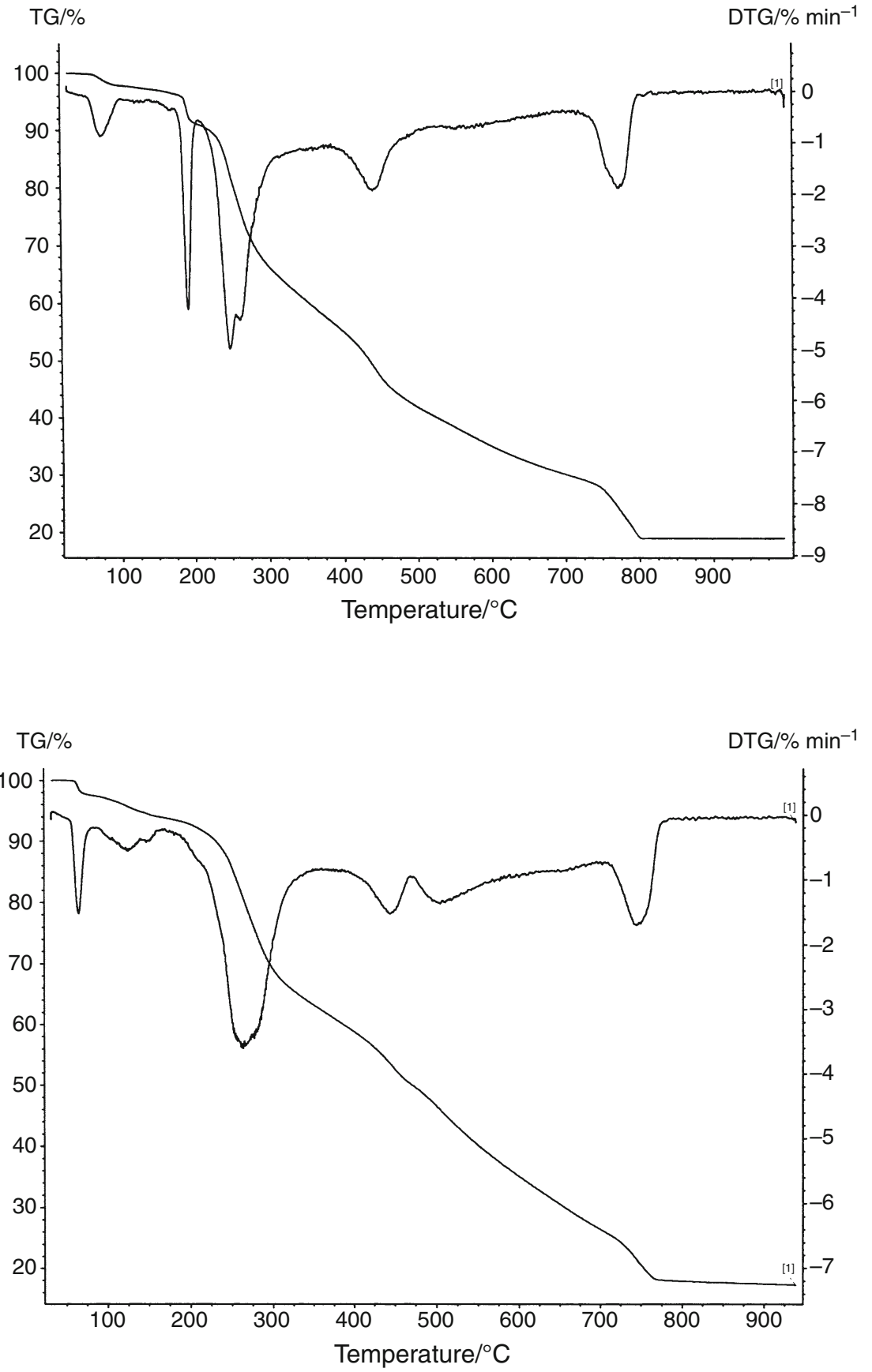

Er(III) complex is stable up to $50{ }^{\circ} \mathrm{C}$. Dehydration process occurs in two steps. Above $50{ }^{\circ} \mathrm{C}$, one and half water molecules are lost $\left(50-80{ }^{\circ} \mathrm{C}\right)$. The second step takes place between 80 and $145^{\circ} \mathrm{C}$. It is connected with leaving the remaining water. On DTG curve, there are peaks at $65^{\circ}$ and $125^{\circ}$ with shoulder at $150^{\circ} \mathrm{C}$. With increasing temperature is partial and total destroying of organic ligands probably via $\mathrm{Er}(4-\mathrm{bpy})_{1.5}\left(\mathrm{CBr}_{2} \mathrm{HCOO}\right)_{0.5} \cdot \mathrm{Br}_{2.5}$. Above $775{ }^{\circ} \mathrm{C}$, pure $\mathrm{Er}_{2} \mathrm{O}_{3}$ appears.

\section{TG-MS study for $\mathrm{Tb}$ (III) and $\operatorname{Er}$ (III) complexes in air}

Moreover, TG-MS system was used to analyze the principal volatile products evolved during thermal decomposition and fragmentation in dynamic air atmosphere. TGMS study was made only for terbium(III) (as a representative of isostructural compounds) and erbium(III) complexes. The detection of volatile species and fragmentation 
Table 4 Thermal decomposition data for obtained complexes in air atmosphere

\begin{tabular}{|c|c|c|c|c|c|}
\hline \multirow[t]{2}{*}{ Complex } & \multirow{2}{*}{$\begin{array}{l}\text { Temperature } \\
\text { range } /{ }^{\circ} \mathrm{C}\end{array}$} & \multirow{2}{*}{$\begin{array}{l}\text { Principal peaks of DTG } \\
\text { temperature } /{ }^{\circ} \mathrm{C}\end{array}$} & \multicolumn{2}{|c|}{ Mass loss $/ \%$} & \multirow[t]{2}{*}{ Intermediate and final solid products } \\
\hline & & & Calc. & Found. & \\
\hline \multirow[t]{5}{*}{$\mathrm{Gd}(4-\mathrm{bpy})\left(\mathrm{CBr}_{2} \mathrm{HCOO}\right)_{3} \cdot 3 \mathrm{H}_{2} \mathrm{O}$} & $75-100$ & 80 & 1.77 & 1.8 & $\mathrm{Gd}(4-\mathrm{bpy})\left(\mathrm{CBr}_{2} \mathrm{HCOO}\right)_{3} \cdot 2 \mathrm{H}_{2} \mathrm{O}$ \\
\hline & $100-200$ & 160 & 3.54 & 3.2 & $\mathrm{Gd}(4-\mathrm{bpy})\left(\mathrm{CBr}_{2} \mathrm{HCOO}\right)_{3}$ \\
\hline & $200-220$ & 205 & 3.67 & 4.0 & $\mathrm{Gd}(4-\mathrm{bpy})\left(\mathrm{CBr}_{2} \mathrm{HCOO}\right)_{2.75} \mathrm{Br}_{0.25}{ }^{\mathrm{b}}$ \\
\hline & $220-290$ & 245 & 23.23 & 23.0 & $\mathrm{Gd}(4-\mathrm{bpy})\left(\mathrm{CBr}_{2} \mathrm{HCOO}\right) \mathrm{Br}_{2}{ }^{\mathrm{a}}$ \\
\hline & $290-835$ & $330,440,815$ & 49.99 & 49.5 & $\mathrm{Gd}_{2} \mathrm{O}_{3}$ \\
\hline \multirow[t]{5}{*}{$\mathrm{Tb}(4$-bpy $)\left(\mathrm{CBr}_{2} \mathrm{HCOO}\right)_{3} \cdot 3 \mathrm{H}_{2} \mathrm{O}$} & $75-100$ & 80 & 1.77 & 1.80 & $\mathrm{~Tb}(4-\mathrm{bpy})\left(\mathrm{CBr}_{2} \mathrm{HCOO}\right)_{3} \cdot 2 \mathrm{H}_{2} \mathrm{O}$ \\
\hline & $100-155$ & 135 & 3.54 & 3.5 & $\mathrm{~Tb}(4-$ bpy $)\left(\mathrm{CBr}_{2} \mathrm{HCOO}\right)_{3}$ \\
\hline & $155-220$ & 200 & 6.70 & 6.5 & $\mathrm{~Tb}(4-\mathrm{bpy})\left(\mathrm{CBr}_{2} \mathrm{HCOO}\right)_{2.5} \mathrm{Br}_{0.5}{ }^{\mathrm{b}}$ \\
\hline & $220-290$ & 245 & 20.11 & 20.0 & $\mathrm{~Tb}(4-\mathrm{bpy})\left(\mathrm{CBr}_{2} \mathrm{HCOO}\right) \mathrm{Br}_{2}{ }^{\mathrm{a}}$ \\
\hline & $290-750$ & 430,660 & 49.55 & 49.5 & $\mathrm{~Tb}_{4} \mathrm{O}_{7}$ \\
\hline \multirow[t]{4}{*}{ Dy $(4-b p y)\left(\mathrm{CBr}_{2} \mathrm{HCOO}\right)_{3} \cdot 3 \mathrm{H}_{2} \mathrm{O}$} & $60-125$ & 75 & 2.64 & 2.5 & $\mathrm{Dy}(4-\mathrm{bpy})\left(\mathrm{CBr}_{2} \mathrm{HCOO}\right)_{3} \cdot 1.5 \mathrm{H}_{2} \mathrm{O}$ \\
\hline & $125-200$ & 185 & 5.99 & 6.0 & Dy(4-bpy) $\left(\mathrm{CBr}_{2} \mathrm{HCOO}\right)_{2.75} \mathrm{Br}_{0.25}{ }^{\mathrm{b}}$ \\
\hline & $200-350$ & $250,260 \mathrm{sh}$ & 30.11 & 30.0 & Dy(4-bpy) $\left(\mathrm{CBr}_{2} \mathrm{HCOO}\right)_{0.5} \mathrm{Br}_{2.5}{ }^{\mathrm{a}}$ \\
\hline & $350-800$ & 430,770 & 43.04 & 43.0 & $\mathrm{Dy}_{2} \mathrm{O}_{3}$ \\
\hline \multirow[t]{4}{*}{$\mathrm{Er}(4-\mathrm{bpy})_{1.5}\left(\mathrm{CBr}_{2} \mathrm{HCOO}\right)_{3} \cdot 3 \mathrm{H}_{2} \mathrm{O}$} & $50-80$ & 65 & 2.44 & 2.5 & $\mathrm{Er}(4-\mathrm{bpy})_{1.5}\left(\mathrm{CBr}_{2} \mathrm{HCOO}\right)_{3} \cdot 1.5 \mathrm{H}_{2} \mathrm{O}$ \\
\hline & $80-145$ & $125,150 \mathrm{sh}$ & 2.44 & 2.5 & $\operatorname{Er}(4-b p y)_{1.5}\left(\mathrm{CBr}_{2} \mathrm{HCOO}\right)_{3}$ \\
\hline & $145-340$ & 260 & 30.96 & 31.0 & $\operatorname{Er}(4-b p y))_{1.5}\left(\mathrm{CBr}_{2} \mathrm{HCOO}\right)_{0.5} \mathrm{Br}_{2.5}{ }^{\mathrm{a}, \mathrm{b}}$ \\
\hline & $340-775$ & $440,500,745$ & 46.87 & 46.0 & $\mathrm{Er}_{2} \mathrm{O}_{3}$ \\
\hline
\end{tabular}

sh shoulder

a Projected by DTG curve on TG curve

b In the sinters of several solid intermediate products, bromide anions and IR bands' characteristic for carboxylate groups and 4,4'-bipyridine were identified

Fig. 7 Ion current vs time for terbium(III) complex of volatile products contain bromine atom; mass sample $10.80 \mathrm{mg}$

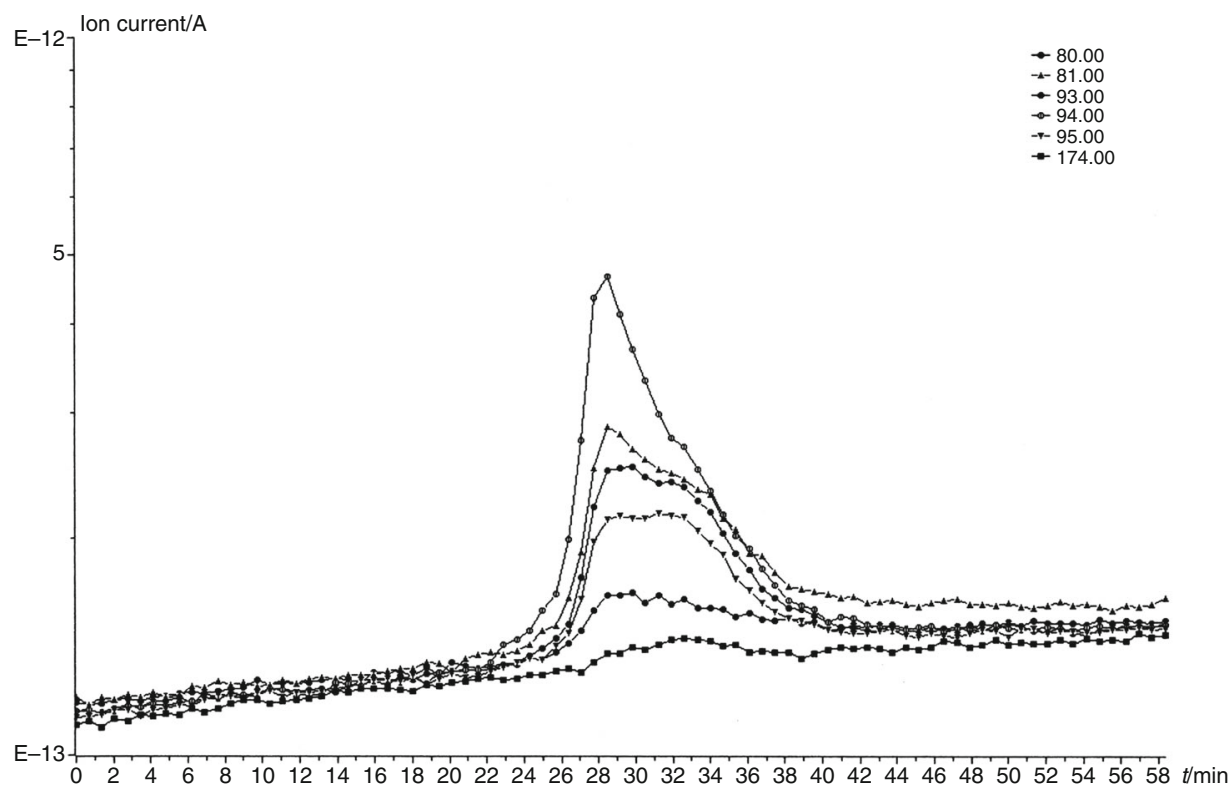

in appropriate temperature range $\left(270-370{ }^{\circ} \mathrm{C}\right.$ for $\mathrm{Tb}$ (IIII) and $260-360{ }^{\circ} \mathrm{C}$ in case of $\operatorname{Er}(\mathrm{III})$ ) correspond exactly to the sudden mass loss presented in Table 4. Major maxima for ion current are for $\mathrm{Tb}(\mathrm{III})$ at: 270,450 and $680{ }^{\circ} \mathrm{C}$. In case of $\operatorname{Er}($ III) compound, they are at: 265, 455, 514 and $720{ }^{\circ} \mathrm{C}$. The peak characteristic for $\mathrm{OH}^{+}, \mathrm{H}_{2} \mathrm{O}^{+}(\mathrm{m} / \mathrm{z}=17$, 18) appears as a broad maximum in the temperature range 90-320 ${ }^{\circ} \mathrm{C}$. It connects with dehydration and partial 
decomposition dibromoacetate ligands. For terbium(III) complex, the profiles of $\mathrm{C}^{+}$and $\mathrm{CO}_{2}{ }^{+}(\mathrm{m} / \mathrm{z}=12,44,45$, 46) are maximum at $180^{\circ}$ and $233^{\circ}$, and with very high intensity at $280,460,517$ and $694^{\circ} \mathrm{C}$. In case of the erbium(III) compound, they are at: $146^{\circ}$ (with low intensity), $270,455,515$ and $720^{\circ} \mathrm{C}$. For investigated complexes, the bromide species corresponding to $m / z=80\left(\mathrm{Br}^{+}\right), 81$ $\left(\mathrm{HBr}^{+}\right), 93\left(\mathrm{CHBr}^{+}\right), 94\left(\mathrm{CH}_{2} \mathrm{Br}^{+}\right), 95\left(\mathrm{CH}_{3} \mathrm{Br}^{+}\right), 174$ $\left(\mathrm{CH}_{2} \mathrm{Br}_{2}^{+}\right)$are in the temperature range $250-400{ }^{\circ} \mathrm{C}$. It is associated with destruction of dibromoacetates. There are also fragments $m / z=15\left(\mathrm{CH}_{3}{ }^{+}\right.$or $\left.\mathrm{NH}^{+}\right)$and $30\left(\mathrm{CH}_{2} \mathrm{O}^{+}\right.$ or $\mathrm{NO}^{+}$). Maximum formation of $\mathrm{CH}_{3}^{+}$or $\mathrm{NH}^{+}$is at $280{ }^{\circ} \mathrm{C}$. Evolution of $\mathrm{CH}_{2} \mathrm{O}^{+}$or $\mathrm{NO}^{+}$is at $670{ }^{\circ} \mathrm{C}(\mathrm{Tb}(\mathrm{III}))$ and $725{ }^{\circ} \mathrm{C}(\mathrm{Er}(\mathrm{III}))$. The mass spectrometer detected also traces of other ion signals. Figure 7 presents hemogram of $\mathrm{Tb}$ (III) complex consisting of only principal bromide species versus time.

\section{Conclusions}

1. In this paper, there is information about obtained complexes of Gd(III), Tb(III), Dy(III) and $\mathrm{Er}(\mathrm{III})$ with empirical formulae: $\mathrm{Ln}(4-\mathrm{bpy})\left(\mathrm{CBr}_{2} \mathrm{HCOO}\right)_{3} \cdot 3 \mathrm{H}_{2} \mathrm{O}$ (where $\operatorname{Ln}(\mathrm{III})=\mathrm{Gd}, \mathrm{Tb}$, Dy) and $\operatorname{Er}(4-\mathrm{bpy})_{1.5}\left(\mathrm{CBr}_{2}\right.$ $\mathrm{HCOO})_{3} \cdot 3 \mathrm{H}_{2} \mathrm{O}$. All compounds were synthesized in the same experimental conditions.

2. The compounds of $\mathrm{Gd}(\mathrm{III}), \mathrm{Tb}(\mathrm{III})$ and $\mathrm{Dy}(\mathrm{III})$ are isostructural in one group.

None of the obtained complexes is isostructural of compounds of $\mathrm{Y}(\mathrm{III}), \mathrm{La}(\mathrm{III}) \rightarrow \mathrm{Eu}(\mathrm{III}) \quad$ (without Pm(III)) with 4,4'-bipyridine and dibromoacetates $[14,15]$.

3. The IR spectroscopy data for obtained $\mathrm{Gd}(\mathrm{III}), \mathrm{Tb}(\mathrm{III})$, Dy(III) and Er(III) compounds confirm that the metal ions(III) are bonded with title ligands. The shifts of bands characteristic for $v_{\mathrm{as}}(\mathrm{COO})$ and $v_{\mathrm{s}}(\mathrm{COO})$ vibrations in complexes correspond to bridging nature of carboxylate groups.

4. During heating in air, all complexes decompose in multistage. Some stages of pyrolysis are weakly separated one from another. Decomposition of investigated compounds begins with total or partial loss of water. Elevation of temperature is connected with partial destruction of ligands containing bromides. The final solid residues are pure oxides.

5. MS data for $\mathrm{Tb}(\mathrm{III})$ and $\mathrm{Er}(\mathrm{III})$ complexes detected several profiles of ion currents. The principal volatile products evolved during thermal decomposition and fragmentation processes in dynamic air atmosphere are: $\mathrm{OH}^{+}, \mathrm{H}_{2} \mathrm{O}^{+}, \mathrm{C}^{+}, \mathrm{CO}_{2}^{+}, \mathrm{Br}^{+}, \mathrm{HBr}^{+}, \mathrm{CHBr}^{+}$, $\mathrm{CH}_{2} \mathrm{Br}^{+}, \mathrm{CH}_{3} \mathrm{Br}^{+}, \mathrm{CH}_{2} \mathrm{Br}_{2}^{+}, \mathrm{CH}_{2} \mathrm{O}^{+}$or $\mathrm{NO}^{+}, \mathrm{CH}_{3}{ }^{+}$or $\mathrm{NH}^{+}$.
Open Access This article is distributed under the terms of the Creative Commons Attribution 4.0 International License (http:// creativecommons.org/licenses/by/4.0/), which permits unrestricted use, distribution, and reproduction in any medium, provided you give appropriate credit to the original author(s) and the source, provide a link to the Creative Commons license, and indicate if changes were made.

\section{References}

1. Weimin L, Yiqiang C, Nan D, Jianming G, Chenggang C. Synthesis, characterization and crystal structure of diaquadi $\left(2,2^{\prime}\right.$ bipyridine)di(dichloroacetato)lanthanide(III) monodichloroacetato. J Coord Chem. 1994;35:51. doi:10.1080/00958979508033085.

2. Rohde A, John D, Urland W. Crystal structures of $\mathrm{Gd}_{2}\left(\mathrm{Cl}_{3}\right.$ CCOO $)_{6}(\text { bipy })_{2}\left(\mathrm{H}_{2} \mathrm{O}\right)_{2} \cdot 4$-bipy, $\quad \operatorname{Pr}\left(\mathrm{Cl}_{3} \mathrm{CCOO}\right)_{3}(\text { bipy })_{2}, \quad \mathrm{Nd}\left(\mathrm{Cl}_{3}\right.$ $\mathrm{CCOO})_{3}(\text { bipy })_{2}$ and $\mathrm{Er}\left(\mathrm{Cl}_{3} \mathrm{CCOO}\right)_{3}(\text { bipy })_{2}\left(\mathrm{H}_{2} \mathrm{O}\right)$. Z Kristal. 2005;220(2):177. doi:10.1524/zkri.220.2.177.59141.

3. John D, Urland W. Crystal structure and magnetic behaviour of the new gadolinium complex compound $\mathrm{Gd}_{2}\left(\mathrm{ClH}_{2} \mathrm{CCOO}\right)_{6}$ (bipy) $)_{2}$. Eur J Inorg Chem. 2005;22:4486. doi:10.1002/ejic.200500734.

4. Rohde A, Urland J. Catena-Poly[[(2,2'-bipyridine- $\left.\kappa^{2} \mathrm{~N}, \mathrm{~N}^{\prime}\right)$-praseodymium(III)]- $\mu$-dichloroacetate-1 $\kappa^{2} \mathrm{O}: \mathrm{O}^{\prime}: 2 \kappa \mathrm{O}$-di- $\mu$-dichloroacetato- $\left.\kappa^{4} \mathrm{O}: \mathrm{O}^{\prime}\right]$. Acta Cryst. 2006;E62:2843. doi:10.1107/S160053680603995X.

5. Rohde A, Urland J. Catena-Poly[[(2,2'-bipyridine- $\left.\kappa^{2} \mathrm{~N}, \mathrm{~N}^{\prime}\right)$ neodymium(III)]- $\mu$-dichloroacetate- $1 \kappa^{2} \mathrm{O}: \mathrm{O}^{\prime}: 2 \kappa \mathrm{O}-\mathrm{di}-\mu-$ dichloroacetato- $\left.\kappa^{4} \mathrm{O}: \mathrm{O}^{\prime}\right]$. Acta Cryst. 2006;E62:1618. doi:10. $1107 / \mathrm{S} 1600536806022872$.

6. Czylkowska A, Kruszynski R, Czakis-Sulikowska D, Markiewicz M. Coordination polymer of lanthanum: synthesis, properties and crystal structure of $\left[\mathrm{La}\left(4,4^{\prime} \text {-bipyridine }\right)\left(\mathrm{CCl}_{2} \mathrm{HCOO}\right)_{3}\left(\mathrm{H}_{2} \mathrm{O}\right)\right]_{n}$. J Coord Chem. 2007;60(24):2659-69.

7. Kruszyński R, Czylkowska A, Czakis-Sulikowska D. A novel carboxylic coordination polymer of samarium(III): $\left[\mathrm{Sm}\left(\mathrm{H}_{2} \mathrm{O}\right)\left(4,4^{\prime}\right.\right.$ bipyridine $\left.)\left(\mathrm{CCl}_{2} \mathrm{HCOO}\right)_{3}\right]_{\mathrm{n}}$. J Coord Chem. 2006;59(6):681-90.

8. Czylkowska A, Markiewicz M. Coordination behaviour and thermolysis of some rare-earth complexes with 4,4'-bipyridine and di- or trichloroacetates. $\mathrm{J}$ Therm Anal Calorim. 2010;100(2):717-23.

9. Czylkowska A, Czakis-Sulikowska D, Kruszynski R, Markiewicz M. Synthesis, crystal structure and other properties of the complexes of $\operatorname{Er}(\mathrm{III}), \mathrm{Yb}(\mathrm{III})$ and $\mathrm{Lu}(\mathrm{III})$ with 4,4'-bipyridine and dichloroacetates. Struct Chem. 2010;21(2):415-23.

10. Czylkowska A, Czakis-Sulikowska D, Kaczmarek A, Markiewicz M. Thermal behavior and other properties of $\operatorname{Pr}(\mathrm{III}), \mathrm{Sm}(\mathrm{III})$, $\mathrm{Eu}(\mathrm{III}), \mathrm{Gd}(\mathrm{III}), \mathrm{Tb}(\mathrm{III})$ complexes with 4,4'-bipyridine and trichloroacetates. J Therm Anal Calorim. 2011;105(1):331-9.

11. Czakis-Sulikowska D, Czylkowska A, Markiewicz M. Synthesis, characterization and thermal decomposition of yttrium and light lanthanides with 4,4'-bipyridine and dichloroacetates. Polish J Chem. 2007;81(7):1267-75.

12. Czakis-Sulikowska D, Czylkowska A, Markiewicz M, Frajtak M. Synthesis and properties of complexes of Gd(III), Tb(III), Ho(III) and Tm(III) with 4,4'-bipyridine and dichloroacetates. Polish J Chem. 2009;83(11):1893-901.

13. Czylkowska A. New complexes of heavy lanthanides with $4,4^{\prime}$ bipyridine and trichloroacetates. $\mathrm{J}$ Therm Anal Calorim. 2011;105(1):331-9.

14. Czylkowska A, Markiewicz M. Synthesis, thermal behavior, and other properties of $\mathrm{Y}(\mathrm{III})$ and $\mathrm{La}(\mathrm{III})$ complexes with $4,4^{\prime}$ bipyridine and trichloro-or dibromoacetates. J Therm Anal Calorim. 2012;109(2):727-34.

15. Czylkowska A. Synthesis and some properties of light lanthanide complexes with 4,4'-bipyridine and dibromoacetates: thermal study. J Therm Anal Calorim. 2013;114:989. 
16. Powder Diffraction File, PDF-2. The International Centre for Diffraction Data (ICDD) 12 Campus Boulevard, Newton Square, PA, USA 2004.

17. Geary WI. The use of conductivity measurements in organic solvents for the characterisation of coordination compounds. Coord Chem Rev. 1971;7:81-122. doi:10.1016/S0010-8545(00)80009-0.

18. Harris CM, McKenzie ED. Nitrogenous chelate complexes of transition metals.III. Bis-chelate complexes of nickel(III) with 1,10-phenantroline, 2,2'-bipyridyl and analogous ligands. J Inorg Nucl Chem. 1967;29(4):1047-68.

19. Feltman RD, Hayter RG. The electrolyte type of ionized complexes. J Chem Soc 1964;4587-91.

20. Spinner E. The vibration spectra of some substituted acetate ions. J Chem Soc 1964;4217.

21. Pearce CK, Grosse DW, Hessel W. Effect of molecular structure on infrared spectra of six isomers of bipyridine. Chem Eng Data. 1970;15:567-70. doi:10.1021/je60047a042.
22. Manhas BS, Trikha AK. Relationships between the direction of shifts in the carbon-oxygen stretching frequencies of carboxylato complexes and the type of carboxylate coordination. Indian $\mathbf{J}$ Chem. 1982;59:315-9.

23. Liu J-Y, Ren N, Zhang J-J, He S-M, Wang S-P. Crystal structures, thermal properties, and biological activities of a series of lanthanide compounds with 2,4-dichlorobenzoic acid and 1,10phenanthroline. Ind Eng Chem Res. 2013;52:6156-63.

24. Zhang Y-Y, Ren N, Xu S-L, Zhang J-J, Zhang D-H. A series of binuclear lanthanide(III) complexes: crystallography, antimicrobial activity and thermochemistry properties studies. J Mol Struct. 2015;1081:413-25.

25. Brzyska W, Ożga W. Spectral, magnetic and thermal investigations of some $d$-electron element 3-methoxy-4-methylbenzoates. J Therm Anal Calorim. 2006;84:385-9. doi:10.1007/s10973-005$6855-9$. 